\title{
3. 映像のパケット伝送
}

\section{1. ま え がき}

音声, データ, 画像等の各種メディアの情報源が発 生する瞬時情報は，多かれ少なかれバースティー（間 欠的）である。ところが, 広域網の主体である電話網 はもちろん, 現在各国で構築されている $2 \mathrm{~B}+\mathrm{D}$ を基 本インタフェースとするISDN（ここでは狭帯域 ISDN という）は，回線交換を主体としたネットワー クであり，これらの情報源に整合していない。また， 情報化社会の進展とともに，ユーザは 1 対 1 接続ばか りでなく，1対多，多対 1 , あるいは多対多といった 多様な通信接続形態を要求するようになっている.

電話網や狭帯域 ISDN は, 端末・端末間の 1 対 1 通 信接続を主体に構成されたネットワークであって, こ れらの要請に応えられない.さらに, 本格的な動画像 信号は, 電話網や狭帯域 ISDN で取り扱うことは不 可能である．そこで, 来世紀に本格化する高度情報化 社会の最も重要なインフラストラクチャとして, 広帯 域 ISDN の検討が CCITT を中心に現在進められてい る.

この広帯域 ISDN は, 各加入者宅まで光ファイバ ケーブルを引き込み，テレメータ信号など毎秒数ビッ トの超低レートの信号から, 映像信号等毎秒 $100 \mathrm{M}$ ビット以上を要する超高速信号までの任意のレート， 任意のバースティネスの信号を統一的に取り扱うこと を志向している1).

このように性質の大幅に異なる情報源に対しては， 従来の回線交換は伝送路の使用効率の点で, また, パ ケット交換は処理速度の点でいずれも現実的ではな い.そこで，これら両方式の中間的な特徵を持つ高速 パケット交換または高速回線交換が，広帯域 ISDN の有力な伝送交換方式として検討されている213).

これらの方式は，いずれも信号系列をパケット化あ

†東京大学 生産技術研究所

“3. Packetized Video Transmission” by Yasuhiko Yasuda(The Institute of Industrial Science, The University of Tokyo, Tokyo)
正会員 安田 靖 彦 ${ }^{\dagger}$

るいはバースト化するとともに，プロトコルを簡略化 して網内を高速転送するものであり，非同期転送モー ド (ATM : Asynchronous Transfer Mode) と総称さ れている。

この広帯域 ISDN では, 1 対 1 ばかりでなく, 1 対 $N$ (放送型)， $N$ 対 1 (情報収集型) ならびに $N$ 対 $N$ (会議型)の任意の通信接続形態ができるような網構成 がとられると同時に, 統計的に独立な多数の情報源か ら発生するバーストを網内で多重化するので，その大 群化効果によって網資源が効率的に使用される. 一方 ユーザ側に対しては，ネットワークはレートフリーな アクセスを提供する。したがって, 回線交換をべース とした電話網や狭帯域 ISDNにおいて課せられてい た伝送上の制約が取り払われ，端末や方式の設計に一 大インパクトを与えることになる．その典型的な例が 画像あるいは映像の伝送である。

画像は発生情報量が膨大であると同時に咒長度も大 きいので, 従来から各種の帯域圧縮伝送方式が検討さ れ，その一部は実用に供されている。これらの帯域圧 縮方式のほとんどは, 一定レートの伝送路を対象にし たものであった. しかし, 前述した非同期転送モード を用いたネットワークが出現すると, 検討の枠組みが 従来と根底から変わってくるので, 新たな角度から検 討し直す必要が生じる. 最近, このような視点に立つ た研究が各所で開始され，昨年 6 月にはコロンビア大 学通信研究センターにおいて, IEEE COMSOC 主催 の第 1 回パケット化ビデオ通信に関する国際ワークシ ヨップが開催された。

本文では，このような情勢を踏まえて映像パケット 化技術の動向を概説する ${ }^{4)}$.

\section{2. パケット化映像伝送}

パケット化伝送の特色は, 特に動画像伝送の場合に 表れる。ここで映像というのは, 動画像を念頭に置い た画像の表現として用いるが, 必ずしも動画像に限定 しているわけではない。 そこで以後, 映像の代わりに 


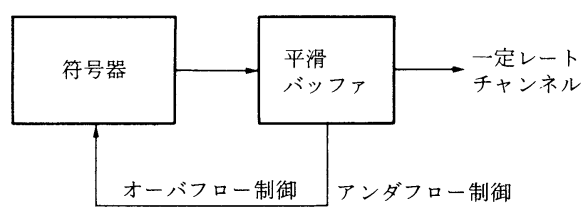

（a）一定レート符号化

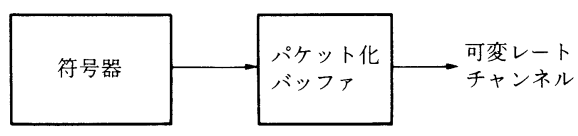

(b) 可変レート符号化

図 1 画像符号化方式

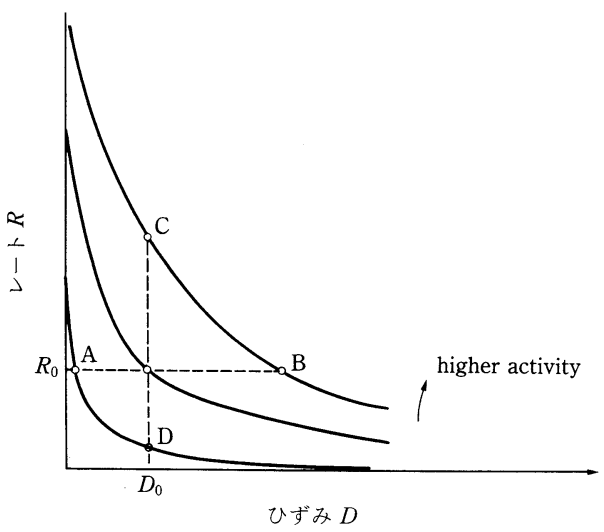

図 2 レートひずみ関数

画像という表現を用いる。図 1 は，一定レートの伝送 路を対象にした従来の画像伝送の送信側 (a) と, レー トフリー（あるいは可変レート）の伝送路を対象にし た画像伝送の送信側 (b) の基本的方式構成を示してい る.

画像が発生する真の瞬時情報量は, 個々の画像や各 画像の部分々々で大幅に変わる。したがって, 符号器 によって圥長度削減操作を行うと，その出力は時間的 に大きく変動する．

一定レートチャンネルを対象にした画像伝送では, このため符号器出力をバッファメモリーで平滑化し, チャンネルへ送り出す必要がある。 バッファの最大容 量はハードウェアコストのほか, 許容遅延時間によっ て制限される。このため, バッファから符号器へフィ ードバック制御を行って, オーバフローやアンダフロ 一の規制を行う。

一方，レートフリーなパケットチャンネルを対象に した画像伝送では，平滑化のためのバッファの代わり に, パケット化のためのバッファを介して伝送路に送
出する. バッファから符号器へのフィードバック制御 は行わず，符号化品質はあらかじめ定めた一定值に保 つことができる。

上述の説明は，図 2 に示すレートひずみ関数を用い て以下のようにいい替えることができる，一定レート の伝送路を対象にする従来の画像符号化では，レート は図の，たとえば $R_{0}$ 点に固定されているので，画面 の活動度に応じて，復号ひずみ（画質）は $\mathrm{AB}$ 間を動 く，一方，レートフリーな伝送路を対象にすると，ひ ずみは，たとえば $D_{0}$ 点に固定することができ，この ときは画面の活動度に応じてレートが CD 間を動くこ とになる ${ }^{5)}$.

\section{3. パケット化映像伝送の特徵}

パケット化映像伝送の特徴を箇条書きすれば，以下 のようになる。

（1）可変レート符号化による符号化品質の向上

伝送路への情報送出レートの平均を同一とした時， 可変レート方式は一定レート方式より高い符号化品質 を達成することができる6).

（2）レートフリー品質制御

一定レート伝送の時は不可能であった符号化画像の 品質を一定に保つことができ, かつその品質をユーザ の必要に応じて制御することが可能となる7.

（3）画像端末の簡易化・低価格化

大容量バッファメモリーや, 複雑なフィードバック 制御が不要となり，画像伝送端末が簡易化される。ま た，機械的可変副走查制御が現実的でない高速ファク シミリが低速走査で簡単に実現できるという利点もあ $ろ^{8)}$.

（4）パケット網の特徵を利用した新映像通信シス テムの可能性

たとえば，多対地の画像会議システムを構成する場 合，各端末の音声や映像を合成編集するファシリティ が必要である．回線交換網の場合，この機能は網内に 置いた共通ファシリティを使用することになるが，パ ケット網の場合には，このネットワークが本来的に有 する同報機能を用いて，各端末で合成編集を行うこと が可能である．会議参加者は，これにより必ずしも同 一の合成映像を見る必要がなく，より柔軟なシステム が構成できる9.

\section{4. 映像信号のバースト性と統計的多重化}

映像信号を符号化すると，その出力情報量は画面の 活動度の大小によって時間的に著しく変動する。 ATM 網は, 図 3 に示すように多数の互いに独立な符 


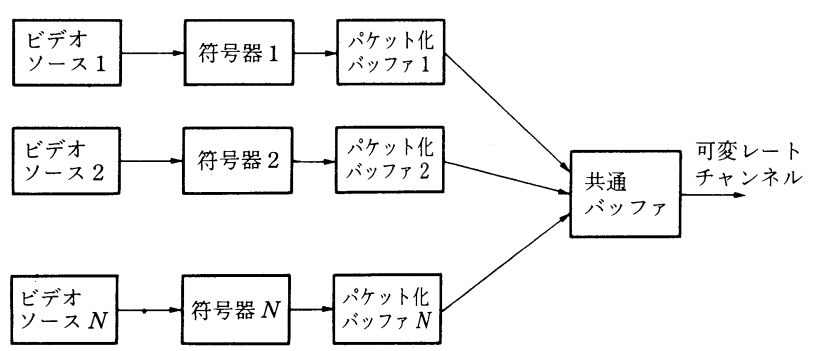

図 3 独立な符号化映像信号の統計的多重化

号化映像信号を多重化して, その統計的大群化効果に よって，伝送路の有効利用を図るものである。したが ってその振舞いを知るためには, 映像信号の出力性, すなわちバースト性を調べる必要がある。

\section{1 符号化映像信号のバースト性}

符号化映像信号の特性は映像信号や符号化方式に依

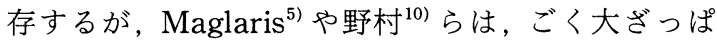
には次式で示す自己回帰過程 (AR 過程) で近似できる ことを明らかにしている。

$$
\begin{aligned}
& I(n)=X(n)+I_{0} \\
& X(n)=\sum_{m=1}^{M} A(m) X(n-m)+e(n)
\end{aligned}
$$

ただし, $I(n): n$ フレーム目の発生情報量

$$
I_{0}: \text { フレーム当たりの平均情報量 }
$$

$$
A(m): \mathrm{AR} \text { モデルパラメータ }
$$

$e(n)$ : 正規乱数

$$
M: \text { モデル次数 }
$$

ここで, モデルの次数は映像信号の性質に応じて選 択する。.

符号化方式として, DCT と動き補償とを用いたフ レーム間符号化方式を用い，2種類の映像を対象に， 符号化出力の自己相関関数の実測值と AR モデルを 当てはめた場合の計算值を図 4 に示す ${ }^{10)}$.

一方, AR モデルはシミュレーションには有効であ るが, 解析的取扱いには不向きであるので, Maglaris らは, 符号化出力系列を離散状態の時間連続マルコ フ過程でモデル化する手法を導入している5).

\section{2 統計的多重化の効果}

図 5 は,フレーム間符号化した独立なテレビ映像信 号を複数チャンネル多重化した時の情報発生レートの 測定值を，1チャンネルに換算して示したものであ る.この測定から, 多重度を上げるにつれて, フレー 厶当たりの情報発生量は平均值の回りに集中し, その 分散が小さくなることがわかる ${ }^{11)}$.

また図 6 は，先に述べた離散状態時間連続マルコフ 過程でモデル化した場合の計算例であって ${ }^{5)}$, バッフ

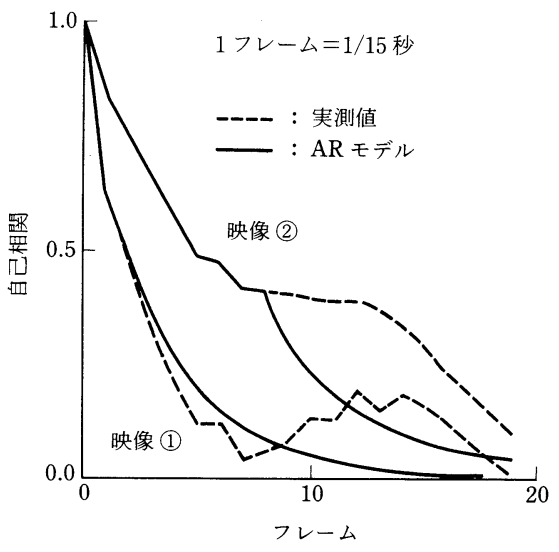

図 4 実測值と AR 過程の自己相関関数

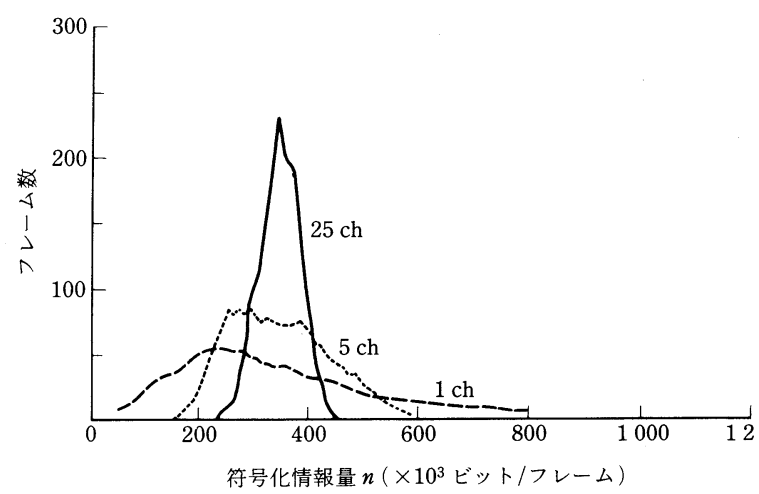

図 5 符号化情報量毎の発生頻度

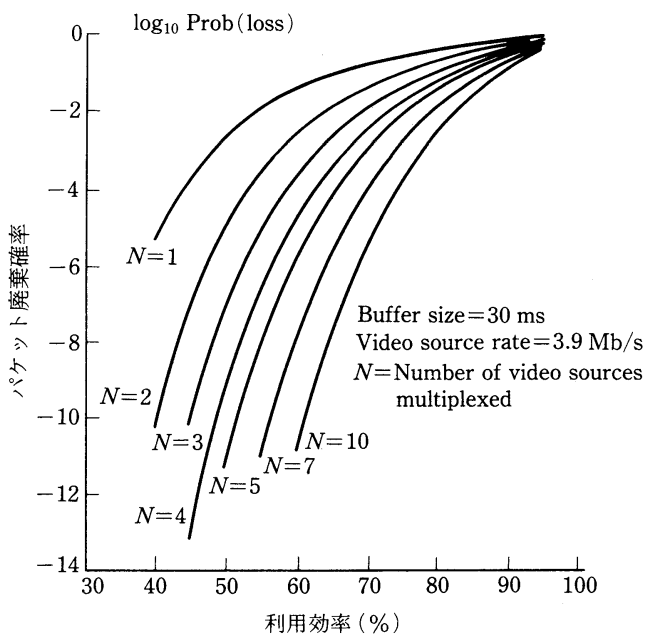

図 6 チャンネル利用効率とパケットオーバフロー廃棄確率

アサイズを一定にして, 多重化チャンネル数 $N$ をパ ラメータとし, 多重化チャンネルの利用効率を変数と して, パケットの廃棄確率を縦軸にプロットしたもの である、これから, 利用効率を一定とした場合, 多重 
度を増すにつれて, バッファのオーバフローによるパ ケット廃棄確率が急速に低下することがわかる。

\section{5. 映像パケット伝送の課題}

映像パケット伝送は, ごく最近登場してきた技術で あるうえに，それが対象とするATM 網自体まだ明 確な仕様が定まっているわけではないので, その実現 には多くの課題が残っている，以下，それらの主なも のについて述べる.

\section{1 パケット廃棄対策}

ATM 網においては, リンクバイリンクのフロー制 御や誤り制御は行わない。したがって小さな確率では あるが, 伝送誤り, 共通バッファのオーバフローある いは過度の伝送遅延によって, パケットが廃棄される 事態が生ずる。

高能率映像信号においては, このパケットロスは, 図 7 に示すように致命的影響を与えるので, その対策 が必要である ${ }^{12)}$. パケット廃棄の原因のうち, 伝送誤 りとバッファオーバフローや過度の伝送遅延とは, 発 生のメカニズムが異なる．よく設計された光通信網で 発生する誤りは, 通常ランダム誤りであって, 各パケ ットで発生する誤りは互いに独立と見なしうる。

一方, バッファのオーバフローや過度の伝送遅延に よるパケット廃棄という事態は, 独立な事象ではな い.あるパケットがオーバフローを起こしたとすれ ば，それに続くパケットのオーバフロー確率は，各パ ケットの平均のオーバフロー確率より高いと考えられ る.

伝送誤りに対しては, 誤り訂正符号を利用するな り，同一パケットを複数回送信するなりの手法で比較 的簡単に対処できる。一方後者に対しては，パケット をインタリーブ構成したり, 階層的符号化伝送を用い る方法が検討されている(6)13).

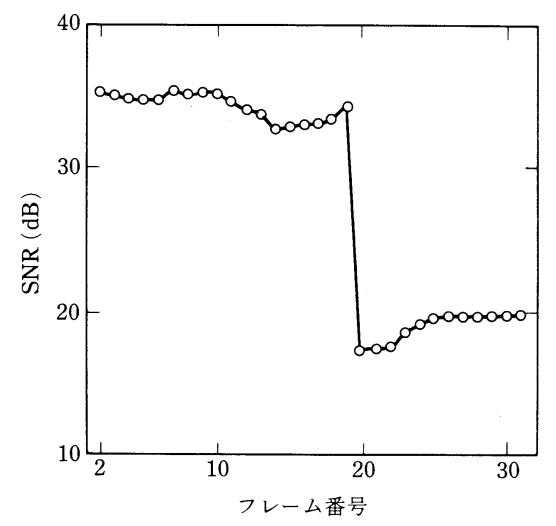

図 7 パケット廃棄時の SNR 劣化
階層的符号化では, 各フレームは原画像情報を底辺 とし, 順次解像度を削減した画情報を上方に積み上げ て構成したピラミッド構造で表現され, 上辺から始め て各階層間の差分を符号化していく ${ }^{14)}$. この時, 最低 面に対応する差分の符号化情報を含むパケットと，そ れより上位の階層に対応する差分の符号化情報を含む パケットとを, 互いにある間隔離して伝送する. 原画 情報に対応する最低面のパケットが誤りを生じたとき は, それより上位のより解像度の低い画像で置き換え ることによってある程度画質が劣化するが, カ夕スト ロフィックな画質劣化を避けることが可能となる.

\section{2 レートフリー品質制御符号化方式}

従来の符号化方式で単純に平滑バッファを取り除く のではなく, より積極的に品質を一定に保持し, かつ その品質を任意に変えられるような符号化方式を開発 する必要がある。またそのとき, 品質自体の評価基準 として最も単純には瞬時 SNRを採ることが考えられ るが, 人間の視覚特性を考慮して, より高度の客観的 評価を確立する必要がある。

\section{3 映像信号のバースト性の解明}

符号化映像信号のバースト性については, 先に述べ たように，ある程度の検討がすでに行われている。し かし, 相続ぐパケットのオーバフロー確率の導出等, パケットロス対策上重要な特性の解明を今後, 待行列 理論やシミュレーション等によって行う必要がある.

\section{6. むす び}

広帯域 ISDN が実現した暁には，その中を流れる 量的に主要な情報種別は映像情報となるであろう。逆 に, 映像メディアが主流を占める状況が招来しない限 り，広帯域 ISDN は現実のものとはならないと考え られる。

映像パケット伝送技術は，このような広帯域 ISDN の構想に関連して, 最近クローズアップされた技術で あり,まだコンセプトの段階から大きく踏み出してい るわけではない。

広带域 ISDNの実現には相当の年月を要するが, 映像パケット伝送技術は, パケット交換データ網 ${ }^{8)}$, 各種の $\mathrm{LAN}^{9)}, \mathrm{MAN}^{15)}$, あるいは高速ディジタル専 用線や衛星ディジタル回線 ${ }^{16)}$ を用いて構築された社 内パケット網等, すでに存在する可変レート網に対し ても適用することが可能であり, 今後の検討が待たれ る.

(昭和 63 年 2 月 16 日受付)

\section{〔参 考 文 献〕}

1）安田：“広帯域 ISDN”, 信学会交換・情報ネットワークショ 
ップ資料(Feb., 1987)

2) J.S. Turner: "New Directions in Communications", Proc. 1986 Zurich Seminar A 3

3) J. J. Kulzer, et al. : "Statistical Switching Architecture for Future Services”, Proc. ISS'84 (May, 1984)

4）安田：“映像パケット伝送技術”, 信学会 PCSJ'87 (Sep.,1987)

5) B. Maglaris, et al. : "Performance Analysis of Statistical Multiplexing for Packet Video Sources", GLOBECOM '87, Tokyo, pp.1890-1899(Nov., 1987)

6) W. Verbiest : "Video Coding in an ATD Environment", Proc. Third Int. Conf. on New Systems and Services in Telecommunication, No.3.10 (Liege, Dec., 1986)

7）野村ほか：“バースト多重映像伝送に於ける符号化アルゴリ ズムの検討”, PCSJ '86, No.6.1

8）安田, 飯田：“圧縮符号化したファクシミリ画信号のパケッ 卜化伝送”, 昭 55 年度信学通信部門全大, No.657

9）安田ほか：“ビデオパケット交換による多対地画像会議”, 信 学会情市研資, IN 82-6(May, 1983)

10）野村ほか：“高能率映像符号化における情報量変動のモデル 化”, 信学技報, IN 87-39, pp.7-11

11）岸野ほか：“パケット符号化を考慮した映像信号の統計的性
質”, 信学会 PCSJ'87, No.8-5(Aug., 1987)

12) 岸本: “映像信号のパケット廃棄に対する補償法の一提案”, 信学技報, IN 87-12

13）加藤ほか：“パケット損失に耐性を有する階層的符号化を用 いたパケット化ビデオ通信の一方式”, 信学会 PCSJ'87, No.8 $-6$

14）安田ほか：“階層的符号化法による静止画像の段階的伝送及 び表示”, 信学誌, J63-B, 4, pp.379-386(Apr.,1980)

15) A. A. Lazar, et al.: "Packetized Video on Magnet", Abstracts, 1st Int. Packet Video Workshop. A.5

16) S. Casner: "Experiences with Packet Video over Satellite”, ibid, A.2(May, 1987)

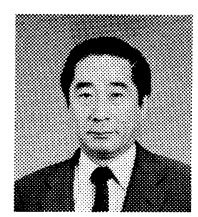

安苗 靖彦 昭和 33 年, 東京大学工学部 電気工学科卒業. 38 年, 同大学院数物系研 究科博士課程修了. 同年, 東京大学生産技術 研究所助教授, 52 年, 同教授. 画像通信, 情報ネットワーク等の研究に従事. 工学博 士. 正会員.

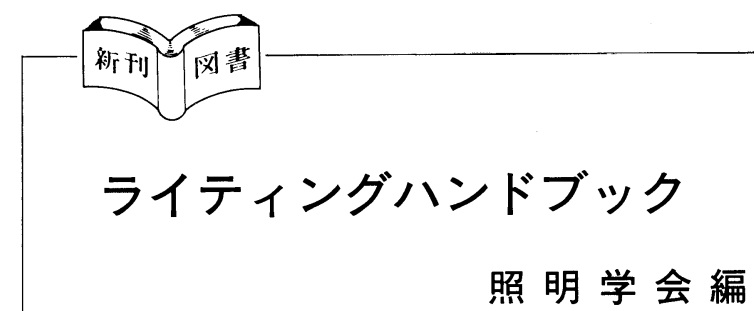

照明学会創立 70 周年を記念して刊行された本書は, 光源, 機器といったハード面のみならず, 照明技術, 意匠, 視覚心理, 色彩技術等のソフト面も含めた統合 技術を集大成したハンドブックである。執筆者は，幅 広い分野の専門家から成っており, 光や視覚の基礎か ら照明設計の実際までバランスよく網羅するととも に, 時代の要請に応え, 最新の照明工学の知識もカバ 一する内容となっている.

本書は, 全 25 章から構成されている。

第 1 章から第 5 章では, 「基礎編」として, 光の性 質と作用, 視覚, 色彩技術, 計測などを解説してい る.

第 6 章から第 9 章では, 「機器編」として, 光関連 材料・光デバイス, 光源と回路, 照明器具, 昼光利用 などについて解説している.

第 10 章から第 14 章では,「照明設計編」として, 照 度・輝度計算法, 視環境, 配線と制御システム, 照明 施設の運用・管理について解説している.

第 15 章から第 23 章では, 「応用編」として, 作業 環境, 公共建築物, スポーツ施設, 劇場抒よび映像,
商業施設, 住宅, 屋外環境, セキュリティ, 交通のた めの照明について解説している.

第 24 章では, 生体・医療, 情報産業などでの新し い応用, また, 第 25 章では, ライティングテクノロ ジーの未来像について述べている.

以上の中から特に本学会に関係の深い技術として, 基礎, 機器関連では, 第 3 章「光と視覚」で, 視覚系 の光学と生理, 視覚系の時空間特性, 明るさと順応, 色覚の心理物理学, 第 5 章「光・放射の計測」で, 測 光標準と測定, 分光測定・測色, 実用計測, コンピュ 一夕援用計測, 第 6 章「光関連材料・光デバイス」で, レーザ, EL, PD 他各種ディスプレイ素子, 光検出 素子, 光ファイバ等が解説されている.

応用技術関連では, 第 8 章「照明器具」で, 配光と 光束計算, 器具の種類と用途, 器具の設計, 器具の試 験方法, 第 18 章「劇場及び映像照明」で, 調光, 色彩, 照明, 光源と色再現性などが解説されている.

以上のように本書は, 照明にかかわる諸技術の基礎 から応用までを解り易く解説しているので, 研究・開 発から応用に携わる幅広い層の技術者に有用な図書で ある。

紹介 阿部正英 (NHK)

照明学会編, オーム社刊 (62 年 11 月 30 日発行), B 5 判 630 頁, 定価 16,000 円 